\title{
THE LEADER PROGRAMME AS A MODEL OF INSTITUTIONAL TRANSFER: LEARNING FROM ITS LOCAL IMPLEMENTATION IN FRANCE AND LITHUANIA
}

Pascal Chevalier ${ }^{1}$, Jurgita Mačiulyté ${ }^{2}$, Lala Razafimahefa ${ }^{3}$, Marc Dedeire ${ }^{4}$

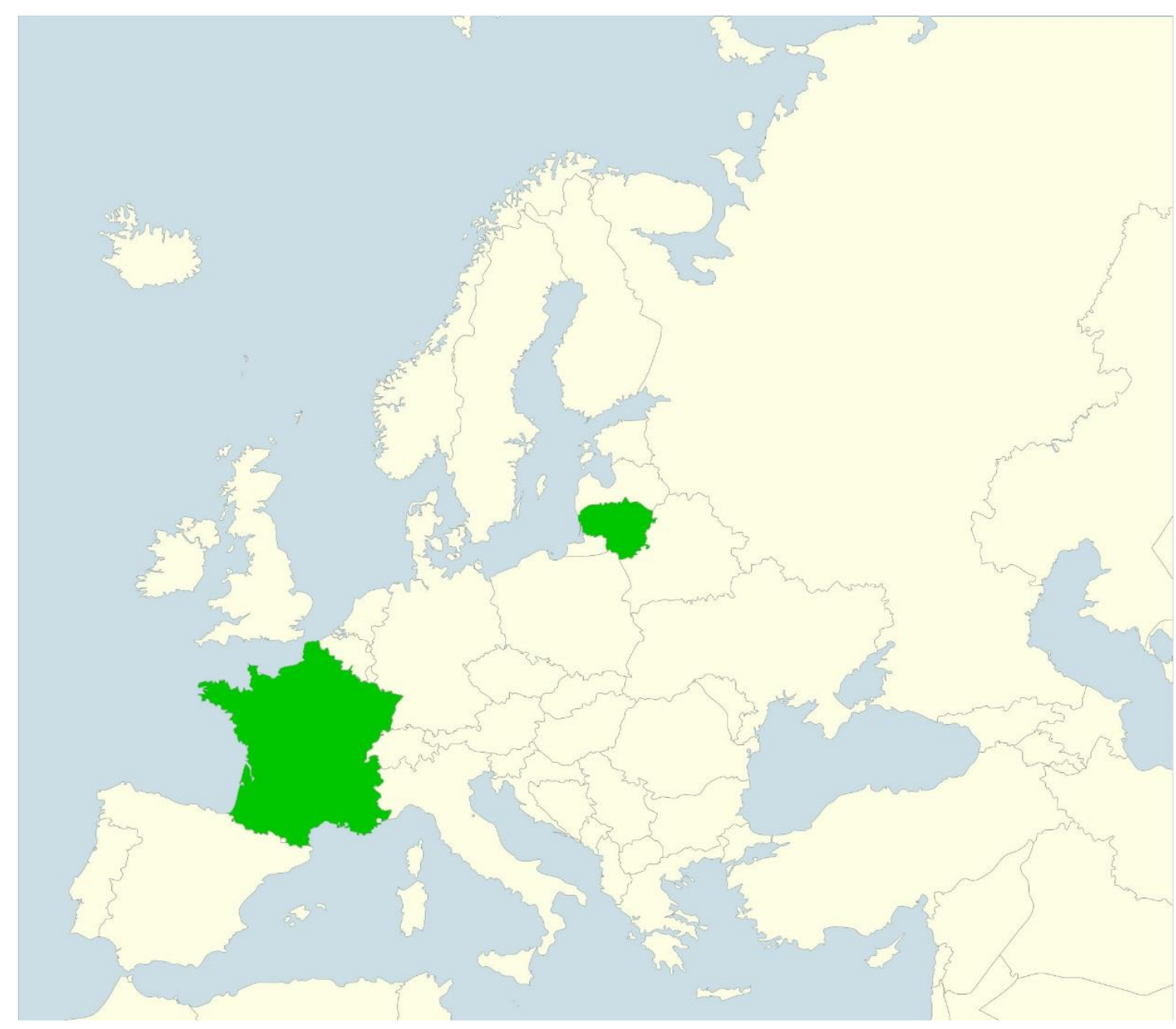

\footnotetext{
${ }^{1}$ Prof. Dr. hab. Pascal Chevalier, Paul Valery University, Montpellier 3, France, Research team: UMR 5281 ART-Dev, pascal.chevalier@univ-montp3.fr

2 Prof. Dr. Jurgita Mačiulytè, Vilnius University, Lithuania, Department of Geography and Land Management, jurgitamaciulyte@hotmail.com

3 Lala Razafimahefa, Statistician Engineer, CNRS, France, Research team: UMR 5281 ART-Dev, lala.razafimahefa@univ-montp3.fr

${ }^{4}$ Prof. Dr. hab. Marc Dedeire, Paul Valery University, Montpellier 3, France, Research team: UMR 5281 ART-Dev, marc.dedeire@univ-montp3.fr
} 
Abstract: Between 2007 and 2013, the European Rural Development Policy targets were supported by the LEADER policy, an instrument that can be interpreted differently according to each country. Based on the examples of France and Lithuania, we studied the way in which the institutional organization of the device at local level helps to understand the stakeholders system and how adaptable it is to situations in each of the corresponding countries and project areas. A comparative approach, based on a joint methodology of investigation and analysis, was used on four project areas: Joniškis and Ignalina in Lithuania, and Gévaudan-Lozère and Pays Cœur d'Hérault in France. It shows that, in all cases, a form of "municipalization" of the LEADER programme, or at least a strong integration of the association sector, is dominant and seems to be established. Studying the network of stakeholders helps to identify the interknowledge as well as the interdependency relationships that lie at the heart of the system. The development of the "social capital of individuals" is often an entry point, if not a cornerstone, of the stakeholders system in place. Finally, it is through the analysis of the project selection process that we can truly grasp the characteristics of the new public action mode, in particular by studying the allocation of projects in these local areas.

Keywords: rural areas, European LEADER programme, rural policies, rural resources, local governance, public action, Lithuania, France

Résumé: Entre 2007 et 2013, les objectifs de la Politique Européenne de Développement Rural ont pu bénéficier de la politique LEADER, instrument pouvant être interprété différemment selon les pays. À partir de deux cas, la France et la Lituanie, nous analysons la façon dont l'organisation institutionnelle du dispositif au niveau local permet de comprendre le système d'acteurs et comment s'adapte-il aux situations de chacun des pays et des territoires de projets correspondant. Une approche comparée, basée sur une méthodologie d'enquête et d'analyse commune, a été réalisée sur quatre territoires de projet, ceux de Joniškis et d'Ignalina en Lituanie, et ceux de Gévaudan-Lozère et de Pays Cœur d'Hérault pour la France. Elle montre que, dans tous les cas, une forme de " municipalisation » du programme LEADER, ou du moins une forte insertion du secteur associatif, domine et semble accomplie. L'analyse du réseau d'acteurs permet d'identifier les relations d'interconnaissance, mais aussi d'interdépendance au sein du système. La formation du « capital social des individus » est souvent une clé d'entrée voire une clé de voûte du système d'acteurs en place. Enfin, c'est à travers l'examen du processus de sélection des projets que l'on peut réellement appréhender les caractéristiques du nouveau mode d'action publique par une analyse de la répartition des projets de ces même territoires locaux.

Mots clés: espace rural, programme européen LEADER, politique rurale, ressources, gouvernance locale, action publique, Lituanie, France

Santrauka: 2007-2013 metais LEADER programa, skirta ir Europos kaimo politikos tikslams igyvendinti, galèjo būti vykdoma skirtingai atskirose šalyse. Straipsnyje, lyginant Prancūzijos ir Lietuvos vietos veiklos grupes (VVG), analizuojama vietos veikèjų sistema, kurios kūrimąsi apibrèžia programos teisinis reglamentas, ir jos pritaikymas atsižvelgiant i kiekvienos šalies ir projekto teritorijos sąlygas lokaliniu lygmeniu. Palyginamasis tyrimas, naudojant tą pačią tyrimo metodiką, buvo vykdomas keturiose projekto teritorijose: Ignalinos ir Joniškio VVG Lietuvoje ir Gévaudan-Lozère bei Pays Cœur d'Hérault Prancūzijoje. Tyrimas parodè, kad vykdant LEADER programą visose projekto teritorijose svarbų vaidmeni vaidina vietos savivaldos institucijos ar bent jau nevyriausybinès organizacijos. Programos dalyvių socialinio tinklo analizè leidžia nustatyti vietinès veiklos sistemą, suformuotą narių tarpusavio pažinojimo ir 
priklausomybès ryšių. Individụ socialinio kapitalo formavimasis yra esminis dalykas vietos veikèjų sistemoje. Taip pat vienas iš tyrimo uždavinių buvo atrinktų vietos projektų tyrimas, kuris leidžia realiai įvertinti naujos viešosios politikos taikymo būdus nagrinėjamose lokalinèse teritorijose.

Raktažodžiai: kaimo erdvè, LEADER programa, kaimo politika, ištekliai, savivalda, viešoji politika, Lietuva, Prancūzija

\section{Introduction}

The enlargement of the European Union (EU) towards central European countries provided conditions conducive to the flow of new public action models and tools. Amongst those, the approach which refers to the paradigm of "local development", tried out successfully in Western Europe, gradually took hold in the new Member States, and in particular those who made up the former communist system. Poles apart from the centralized model which these countries experienced before the collapse of their political system, this approach, based on a bottom-up rationale for local public action, has introduced new mechanisms which allow for responsibility sharing between institutional actors and the civil society. This integrated approach to development on a territorial basis involves steering the efforts and investments towards projects conceived at rural community level in order to strengthen the local stakeholders' ability to take action. This is part of a new method of territorial governance, unprecedented in these countries, which aims at reinforcing local and participatory democracy.

The issue of the institutional transfer of the European local development model to both the old and new Member States makes up the analytical framework of this article, inspired by the policy transfer studies and, in particular, the works of Dolowitz and Marsh (1996). Based on literature relating to learning and convergence, these authors have developed a conceptual framework that helps to understand how the instruments of public action are spread. Other authors associate the concept of transfer to that of Europeanisation (Saurugger and Surel, 2006). They question the impact of the institutions and of the community decisions on the EU Member States in an effort to understand the adjustment, transformation or rejection processes triggered by European integration.

The spread of the LEADER model, taken as an example in this article, is part of the issues surrounding the Europeanisation of public policies. It is based on the assumption that this model can be directly transferred to each State, regardless of the local economic, social or political environments. The LEADER-type intervention relates to the course of public action considered as a whole. As a public policy inspired by the EU, its implementation takes place at the junction of various territorial levels (European, national, regional and local) and relates to a large negotiating arena involving multiple political and social actors. The transfer process is broken down into three sequences: a selection sequence (usually at a supranational level), a transposition sequence (at a national level) and a reception sequence at a local level. Each sequence is met by a specific stakeholder whose action can strengthen or "undermine" the idea of the original model (Chevalier, 2014).

Common to France and Lithuania, and taken as the analytical framework in this article, the European Rural Development Policy targets can be tailored in a flexible manner (according to a "menu" of actions) in order to take into account each country's specific economic and social environment. Both countries are responsible for the implementation of this policy's priorities in the form of programmes that are integrated into their national strategy for rural development. The study of the transfer arrangements of the European Rural Development Policy shows that France and Lithuania translate the LEADER instrument differently (Chevalier, Dedeire 2014).

Far from dealing with the specific way France and Lithuania each transcribe the LEADER policy (on that subject, see Chevalier, 2014), this article looks at the way it is received by the local societies in each of those two countries. In a study with a comparative dimension, we seek to understand how local stakeholders, entrenched in their national institutional context, have owned and interpreted the normative mechanisms and used their resources in order to build 
development strategies. Who are these stakeholders? How do they organize themselves? What is their actual capacity for action?

In order to answer these questions, the article will be based on a detailed analysis of the four LEADER territories - two in France (Pays Cœur d'Hérault and Gévaudan-Lozère in the Languedoc-Roussillon region) and two in Lithuania (Joniškis in the North of the country, and Ignalina in the East). We will look in detail at the make-up and operation of the networks of stakeholders responsible for implementing the LEADER programme at local level. After the presentation of the research process and methodology (part 1), this article will address the way the LEADER model was received by local stakeholders in the four areas studied, their level of involvement and their capacity to take ownership of the normative mechanisms of the local development policy (part 2). The analysis of the creation of Local Action Groups (LAGs) will focus on the role of each type of stakeholder in the local networks' configuration. Based on the review of the projects chosen by the LAGs, the third part will outline an interpretation of the new modes of action across the studied rural community and the transfer limitations of a local development model in all four territorial situations. Lastly, and more broadly, we will examine the issue of the learning from LEADER implementation (part 4).

\section{Research process and methodology}

\subsection{Research process}

At local level, the study focused on the way local stakeholders (civil, political and corporate societies) seized the new public action mechanisms. Their learning ability and interpretation of the local development approach can lead to a transformation of the mode of local governance. The study therefore focused on the analysis of stakeholders' networks responsible for the initiative at local level in four LAGs. In order for the comparative study to be as rigorous as possible, a common methodology (survey protocol with stakeholders, action systems and project areas analysis, project appraisal) was developed (see 1.2. Methodology paragraph below).

As a promoter of local development, the LAG aims to be a coordination mechanism for local stakeholders' initiatives. The LAG's capacity for action is a direct function of the social resources allocated by the partnership members and depends on the coordination mechanisms needed to mobilize them. Once the status of collective stakeholder has been bestowed upon the LAG by the LEADER approach, the analysis of a LAG's development conditions (within the eligibility guidelines of the LEADER programme), of its constitution and of its modus operandi becomes a core element in the understanding of the actual impact of the LEADER programme experiment.

The process behind the study of local action systems, at the heart of this article, draws on the analysis of social networks developed by a stream of sociology as part of the interactionist paradigm. This choice of methodology is consistent with the object of the study, the LAG, created and organized in order to design and implement a local development strategy. We start with the structure created by the network of stakeholders, with an emphasis on the study of the relationships between them in order to understand the LAG's organizational process. Network analysis is first and foremost a method used to contextualize the action that seeks to describe the system of interdependencies between stakeholders and its influence on their behaviour. Compliance with standards of commitment, solidarity and duty of reciprocity between partners can help with the sharing of social resources within the stakeholders' network. The social relationships that develop between them are a channel of choice for these resources to flow. It is therefore the combination of the interdependencies of the stakeholders' network, their social resources (making up the core element of social capital) and the sociability standards that they develop that is defined as the local action system. This local action system, seen as a network of stakeholders, is fully involved in the territorial governance that drives local development; and the bonds between the members of the network can in part explain the collective project's success or failure. The collective action within the network depends on the system of relationships established between its constituent stakeholders. We started with the assumption that the joint undertaking of local development is made possible by the quality and intensity of the interactions within the system of action. The relationships between stakeholders stem from the more or less 
sustainable stabilization of the interactions that emerge within the group and define themselves in terms of cooperation, influence, prestige and authority (Degenne, Forse, 2005).

Our premise, which is structuralist, examines the way social networks operate, not only on the basis of the total number of relationships that develop between individuals, but also on the nature of these relationships that can be more or less dense, more or less equivalent, and more or less connected. These ties are both interknowledge relationships as well as interdependency ones. The former is based on the relational proximity and helps to understand the position of social stakeholders within the network. The study of these relationships, thus enables to "define the network's structure by identifying stakeholders according to their more or less central position. The ties of interknowledge that intertwine (...) form a matrix of social resources which helps individuals who can access them to achieve their projects" (Degenne, Forse, 2005). Driven by the intents of cooperation, the latter reveals the individuals' role and position in the steering of the network and in the increase of its capacity for action. This role and this position play on the individual perceptions that lend a certain prestige or charisma to some LAG members, thereby increasing their ability to influence the collective action regarding the choice and management of some development projects. The benefit of these relationships raises the "individuals' social capital" ${ }^{5}$ and creates a kind of added value which applies to their capacity for action.

We seek to decode the local order that lies behind this system of action in terms of power relationships. How is the self-organized system of stakeholders formed; on the basis of what kind of links does it develop? The pattern of local partnerships and the nature of interests that support strategies and projects clarify the transformation of the mode of local public action.

\subsection{Methodology}

- Step 1 - Identifying the forms of appropriation of the LEADER model through a socialspatial analysis of the actors' network and the project selection process

The methodology for studying the local action systems is inspired by the social network analysis developed by a sociological current within the frame of the interactionist paradigm (Friedberg, 1993; Forse, 2008). We hypothesize that LAGs originate and organize themselves in a complex, unstable and potentially conflicting universe that is of the social interaction. In this research, the boundary of the analyzed network of actors is based on the criterion of membership to the LAG's Board.In order to understand and analyse the local action system that governs the steering of the LEADER programmes, we used a monographic analysis and applied, to all four LAGs under review, the sociological methodology of structural analysis with a view to understanding the relationships between LAG members (Merckle, 2011).

The technique of names generator was used to build the networks: each individual taking part in the investigation was shown a list of names of all the members of their own LAG's Board, and was asked to name people who met three criteria:

- The first criterion, through the question "Please indicate the individuals you know best", set out to investigate the interknowledge ties between the network members and helps to identify their position within the LAG.

- The second criterion, through the question "Which people would you like to work with?", looked at the interdependency ties between them, and therefore the role of each individual within the partnership.

\footnotetext{
${ }^{5}$ For some authors, the concept of social capital indicates the resources that individuals can access through their network of relationships. For others, it applies to the relationship properties (confidence, reciprocity) within the social structure. These definitions are developed in different conceptual frameworks and lend themselves to different uses. Given our interactionist approach, we used the theoretical concepts developed by network sociologists (Burt, Granovetter, Lin) for whom social capital relates to the networks, contacts and resources that individuals seek to access in order to acquire information or strengthen their position in the social structure.
} 
- Finally, the last criterion, through the question "Which person do you hold in the highest regard?" examined stakeholders whose social capital feeds on the charisma or prestige which they enjoy from other LAG members.

Based on the total scores for these three criteria, we specifically worked out the in-degree centrality, defined as the number of contacts received by an individual, to measure his prestige inside the actors' network. Each of those individuals is represented on the sociogram by a node whose size is proportional to his in-degree centrality.

The visual representation of the actors' centrality was completed by a mapping of their position with their individual scores in the municipality where they live. It shows the territorial dimension of the social stakeholders' network configuration. Within a LAG, which brings together several administrative bodies, the geographical positioning of the main stakeholders as well as that of the peripheral ones is important and meaningful. It is also through the main stakeholders' relationships of influence that the balance of power between places plays out.

We also analyzed the appropriation of the LEADER model through a review of the projects selected by the LAG. This allows to understand the characteristics of the mode of public action. These projects are the expression of the choices actually made by local actors. The analysis grid of the projects, that we chose and which has been applied to all the fields of study, takes into account the projects breakdown per commune, their part of funding, and the status of the projects' holders (local institutions, associations or businesses). From there, it is possible to characterise the intentions of the decision-makers who sit within the bodies of the LAG.

- Step 2 - Understanding the local action system through the prism of the national context

According to Chevalier (2012), two kinds of rationale for action allow to interpret the way in which the State actor combines public policy techniques and tools as a framework for the LEADER instrument implementation.

In France, it's a rationale for guidance which conforms to the LEADER paradigm of public action. It stems from a bottom-up approach which postulates that local stakeholders are able to show initiative, form a partnership on a voluntary basis and define a scope of action. At national level, a heterogeneous territorial network is formed with only a partial coverage of the rural areas owing to a selection method of LAG projects based on competition (differentiation principle).

In Lithuania, it's a rationale for intervention which expresses the willingness of the State actor to bend the LEADER instrument to its specific objectives. Consequently, the institutional framework is part of a command and control mode within a top-down approach (Maurel, 2010). Procedures define strict rules for partnership development and scope definition, on the basis of institutionalised networks. The central authority's intention is to impose the network that best suits the instrumentation objective of the LEADER approach in a near-planning and distributive management logic.

We then confront the forms of appropriation of the LEADER model by the local actors, that was previously identified, in relation to the rationale for action proper to each national context.

\subsection{Investigation fields}

The research work is based on the empirical analysis of the structuring of four LAGs, two in France and two in Lithuania.

- The Pays Cœur d'Hérault LAG (France)

The Pays Cœur d'Hérault LAG was created in 1991 and extends from the south of the Massif Central to the Mediterranean edge. It forms a territory bordered to the south by the city of Montpellier. Composed of 77 municipalities, it is organised around four rural poles that are Clermont-l'Hérault, Gignac, Saint-André-de-Sangonis and Lodève. The population was around 70,000 inhabitants in 2015 and increased by more than 25\% between 1999 and 2015 . The location of the Pays gives it a key position at the crossing of two structuring motorway axes, the A75 and A750 highways. The activity is mainly tertiary and is strongly oriented towards residential economy. Agriculture is mostly oriented towards in-plain viticulture, whereas extensive 
sheep breeding prevails in the mountainous areas of Causse du Larzac. There is almost no more industry.

\section{- The Gévaudan-Lozère LAG (France)}

The Gévaudan-Lozère LAG is located on the major western part of the French Massif Central. It was created in 2007, is composed of 120 municipalities organised around two small rural poles, Saint-Flour and Marvejols, and is structured around the A75 highway. With less than 20,000 inhabitants, the LAG is among the least populated project territories in France. It is one of the poorest in the country with an alarming socio-economic situation. Agricultural activity, although weakened, still remains a majority.

- $\quad$ The Ignalina LAG (Lithuania)

The Ignalina LAG is located in the eastern part of Lithuania in the Baltic Hills of Aukstaitija's ethnographic region, on the border with Belarus. It was created in 2007 , is made up of 12 municipalities including one urban, and counts 13,525 inhabitants. A quarter of the territory belongs to the Aukstaitija National Park and has many lakes, a remarkable landscape and important cultural monuments. The activity, mainly touristic, is structured by the road and railway networks connecting cities on a Vilnius-Saint Petersburg axis. Agriculture, otherwise, is poorly developed.

\section{- $\quad$ The Joniškis LAG (Lithuania)}

The Joniškis LAG is located in the north of Lithuania on the border with Latvia in the savivaldybe of Joniškis. Created in 2004, it is composed of 39 rural communities organised around two poles, Joniškis and Žagarè, and counts 19,520 inhabitants. Agriculture, essentially in latifundia form, remains the main economic activity. Non-agricultural activities are poorly developed. The unemployment rate is $7.2 \%$ but, in the most isolated villages, it can reach $16 \%$. The majority of the population live below the poverty line. In 2007, the district of Joniškis was classified as a problem area and was granted financial support from the European Structural Funds for the renovation of infrastructures and public buildings.

\section{Implementation of the LEADER programme in France and Lithuania: towards an interpretation of the tools for local development?}

The LEADER programme is a learning environment for the networking rationale. This learning concept describes the process by which stakeholders acquire new knowledge and skills that lead to a lasting change in their ways of thinking and acting. Here, we focused on a particular type of learning: the uptake by stakeholders of modes of rationalization of their action in the area of local development, an uptake that is supposed to allow them to enhance their ability to identify opportunities, design local development strategies, in order to leverage those opportunities, mobilise means and resources that are available to them in order to achieve their objectives (Delpeuch, Vassileva (2009).

\subsection{From "institutional" organisation to "local" tinkering}

The organization of stakeholders within the LAGs originates from a set of provisions aimed at providing this structure with a capacity for action. Whether in France or in Lithuania, the creation of a LAG is constrained by national rules regarding its composition and organisation that stakeholders must follow in order to take advantage of the system defined by the European policy for rural development and bid for tenders issued within the LEADER framework. In a formal way, the decision-making body of each LAG is the Board of the association. The number and quality of its members, its structure and the way it operates are governed by relevant legislation in each country. Overall, in both countries, the LAG Board must be made up of around thirty members. In France, one-third of them must be local elected officials, one-third businesses headquartered in the LAG area and one-third local associations. In Lithuania, this ratio comes down to at least $50 \%$ for associations, $25 \%$ maximum for businessmen and $25 \%$ maximum for institutions. Everywhere, the Board is appointed by vote and by every member of the LAG association. 
However, all of this does not exclude certain "arrangements or tinkering" (Parrado, 2010) taking place in order to reconcile compliance with the official rules for creating a LAG with the nature of social bonds which exist at local level. Hence, there can be a gap between the theoretical membership as prescribed by the official national rules and the informal structuring mode of the stakeholders who sit on the LAG's bodies. The existence of a gap between prescription and reality can have implications on the group's collective ability to act, whether strengthening it or helping to weaken it. In the four LAGs under review, the very principle of partnership and distribution between three sectors (political, civil and corporate) which provides a solid structural framework, is more or less abused; for example, an elected politician can sit on the Board as an "official" representative of an association or, more informally, on behalf of a company or any other structure of which he/she is also a member.

In the Pays Coeur d'Hérault LAG, more than half of the members representing associations are also elected officials (Mayors and local councillors), the 'three sectors' structure, thus becoming a mere facade behind which local public authority figures conceal themselves.

Tab 1. Official and unofficial representation of the three sectors on the Board of the Gévaudan-Lozère LAG (number of members). Source: Field surveys PHC Gilibert DTAL 2013

\begin{tabular}{|l|c|c|c|}
\hline & Public Sector & $\begin{array}{c}\text { Association } \\
\text { Sector }\end{array}$ & Private Sector \\
\hline Official Representation & 10 & 10 & 10 \\
\hline Unofficial Representation & 19 & 4 & 7 \\
\hline
\end{tabular}

Tab 2. Official and unofficial representation of the three sectors on the Board of the Pays Cœur d'Hérault LAG (number of members). Source: Field surveys PHC Gilibert DTAL 2014

\begin{tabular}{|l|c|c|c|}
\hline & Public Sector & $\begin{array}{c}\text { Association } \\
\text { Sector }\end{array}$ & Private Sector \\
\hline Official Representation & 12 & 12 & 12 \\
\hline Unofficial Representation & 24 & 7 & 5 \\
\hline
\end{tabular}

Tab 3. Official and unofficial representation of the three sectors on the Board of the Joniškis LAG (number of members). Source: Field surveys PHC Gilibert DTAL 2013

\begin{tabular}{|l|c|c|c|}
\hline & Public Sector & $\begin{array}{c}\text { Association } \\
\text { Sector }\end{array}$ & Private Sector \\
\hline Official Representation & 1 & 5 & 2 \\
\hline Unofficial Representation & 1 & 6 & 1 \\
\hline
\end{tabular}

Tab 4. Official and unofficial representation of the three sectors on the Board of the Ignalina LAG (number of members). Source: Field surveys PHC Gilibert DTAL 2014

\begin{tabular}{|l|c|c|c|}
\hline & Public Sector & $\begin{array}{c}\text { Association } \\
\text { Sector }\end{array}$ & Private sector \\
\hline Official Representation & 2 & 5 & 2 \\
\hline Unofficial Representation & 6 & 2 & 1 \\
\hline
\end{tabular}

In the case of Joniškis, the active members of local associations, known as "rural communities", are the ones who are widely represented on the LAG Board. These NGOs, which emerged from 
an original citizen self-organization movement in the mid 1990's, aim to tackle social marginalisation in a context of institutional and democratic deficit at local level. Established in nearly all of the villages, their presence shows the significance of the network of villages inherited from the pre-soviet era. The over-representation of these associations in the LAG network is partly explained by local companies' lack of involvement in rural development (in an important context of rural economic crisis). It is also linked to the low presence of local institutions in an incomplete decentralisation context (Mačiulytè, Daugirdas, 2004).

In Ignalina's LAG, the unofficial representation analysis reveals a strong domination by public sector representatives. Six members of the LAG Board, through their employment or their elected status, are linked to the municipality and the Mayor. Through the LEADER programme, this relational structure achieves the local council's political interests by marginalising the other social stakeholders. Unlike in Joniškis' LAG, rural communities are under-represented in the partnership group and play a minor role in the LEADER programme. The majority of them were created at a late stage and were not strengthened by the former LEADER+ programme. The absence of a local leader representing the social stakeholders' interests, the ageing and multinational structure of the local population and the low density, all act on the low level of involvement of the rural population when it comes to implementing their own projects together.

The rules of "spatial representativeness" of each Board member of the LAG, when they exist, as in France, can also be broadly abused. For example, in the Gévaudan-Lozère LAG, in line with national regulations, all of the partnership's "cantons" had to be represented by a member sitting on the LAG Board, irrespective of their status (elected official, association or businessman). But for the Mayor of the main town, who chairs the LAG, this representativeness obligation for each canton was a real headache. Wondering "how he could integrate a maximum number of stakeholders from his own town, the most dynamic and populated in the area (...), when a maximum of seats are allocated to members of the other rural cantons of the partnership", he went on to explain that "he had to purposely relocate the seat of several associations from his town to neighbouring towns so that they could join the LAG's governing body".

In all of these cases, the "municipalisation" of the LEADER programme or its strong integration in the dominant association sector seems to be established. But doesn't this compromise the prospect of a genuinely participative democracy? There perhaps lies one of the limits to the transfer of the local development model to rural populations. Structures built according to rules that are ready to use remain to some extent virtual, and the presence of certain stakeholders or certain municipalities in these structures is over-represented.

\subsection{What configuration for the action system network?}

As the executing body of development projects carried by local society stakeholders, the LAG appears as a collective actor whose capacity for action can be measured by the ways and level of integration of its members within the cooperation network. More than the situation or the only position of individuals in the global society, these ties can influence the consultation terms that determine, in advance, the priorities chosen regarding the local development strategy. They can also play a role afterwards on the choice of projects selected and financed as part of the LEADER policy.

\section{Gévaudan-Lozère: A network dominated by the local political elites}

In the Gévaudan-Lozère LAG, the position of prestige mainly involves Mayors. The former Mayor of a village in the Lot Valley, former Senator of Lozère and former President of the Regional Council (ind. 48-001), and the current President of the Lozère Regional Council (ind. 48-041) continue to hold a central position within the network. There is also the head of a cultural association for the promotion of Occitan culture. Also Mayor of the village of Montrodat (ind. 48035), he is very close to the two aforementioned politicians, both politically and socially. These leaders belong to a generation of fiftysomethings whose prestige stems from actions they may have carried out in their own municipality, their interest for the local economy and above all their commitment to their territory's development. Through their involvement within partnerships as well as their position on local consultation scene, they wield real political clout. 
In a traditional dignitary-based format, those local politicians mobilize the institutional resources of public action in an instrumental fashion to build up a loyal electorate in their territory (Lefebvre, 2005). The analysis of the nature and qualities of their relationships with other LAG members, who in fact act as "followers" (Callahan 2007), shows that they have a genuine capacity to call upon their traditional institutional networks to develop strategic guidelines, rally partners and direct their action in the name "of some hypothetical common interest" 6 . In the dissemination of the new public action mode, these elected officials (often Mayors) play a key role ${ }^{7}$. As initiators of the approach that led to the creation of the LAGs, which they followed from beginning to end, they are central to the process of bringing into contact partners that they, very often, helped appoint. Such is the case of the association sector representatives who very often belong to the direct sphere of influence of the municipalities. These elected officials may also have asked local businesses directly to take part in the institutional setting up of the project but, in most cases, those are peripheral to the network. Unlike the other LAG members, these local politicians' legitimacy stems from their election as head of a local authority, this authority being even greater if they were re-elected on several occasions. The strengthening of local government through decentralisation or regionalisation has given rise throughout France to these professional Mayors who gained expertise and skills, in particular, through the experience of an intermunicipal management of projects.

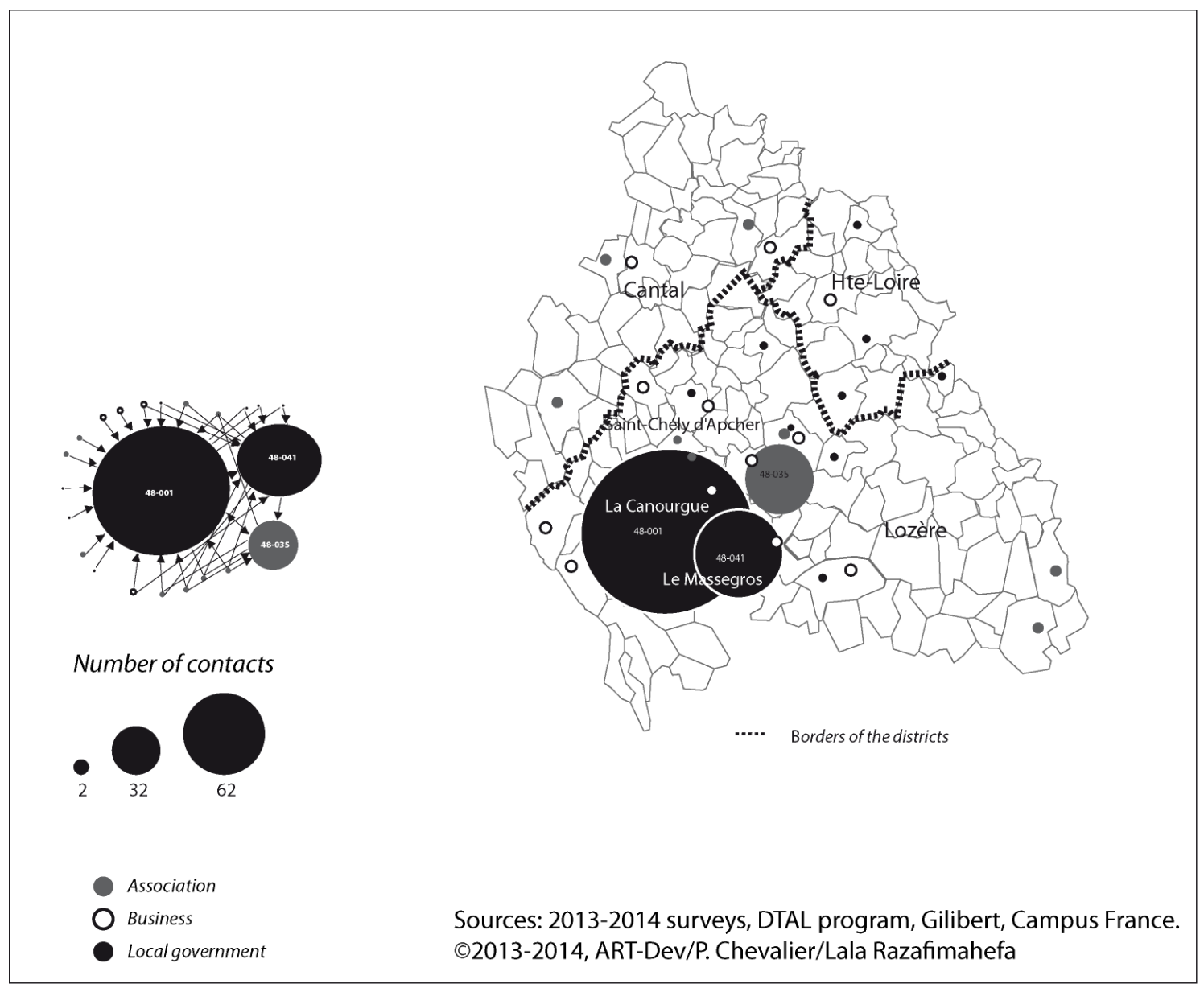

Fig 1. Spatial projection of the centrality regarding the Gévaudan-Lozère LAG.

\footnotetext{
${ }^{6}$ Here we refer to the leadership definition suggested by Keohane N-O. (2010), "Leaders determine or clarify goals for a group of individuals and bring together the energies of members of that group to accomplish those goals", Thinking about leadership, Princeton University Press, p.23.

${ }^{7}$ Keohane N-O. (2010), Thinking about leadership, Princeton University Press.
} 


\section{Pays Cœur d'Hérault: An integrating network}

In Pays Cœur d'Hérault, where leadership appears to be shared between the three sectors (public, association and corporate), five key local figures of whom three are elected officials, clearly hold a central position. First, there is the former MP and Mayor of Lodève, who chairs the LAG (ind. 34-001) and whose prestige and reputation rests on a network of local political actors who are largely on his side. He shares this leadership with the General Councillor for the Lunas canton (ind. 34-009) and the Regional Council representative, who is also a Local Councillor for Gignac (ind. 34-026). Finally, we have the President of the Lodève Tourist Office (ind. 34-056) and a businessman (ind. 34-044), owner of rural gîtes in Bosc.

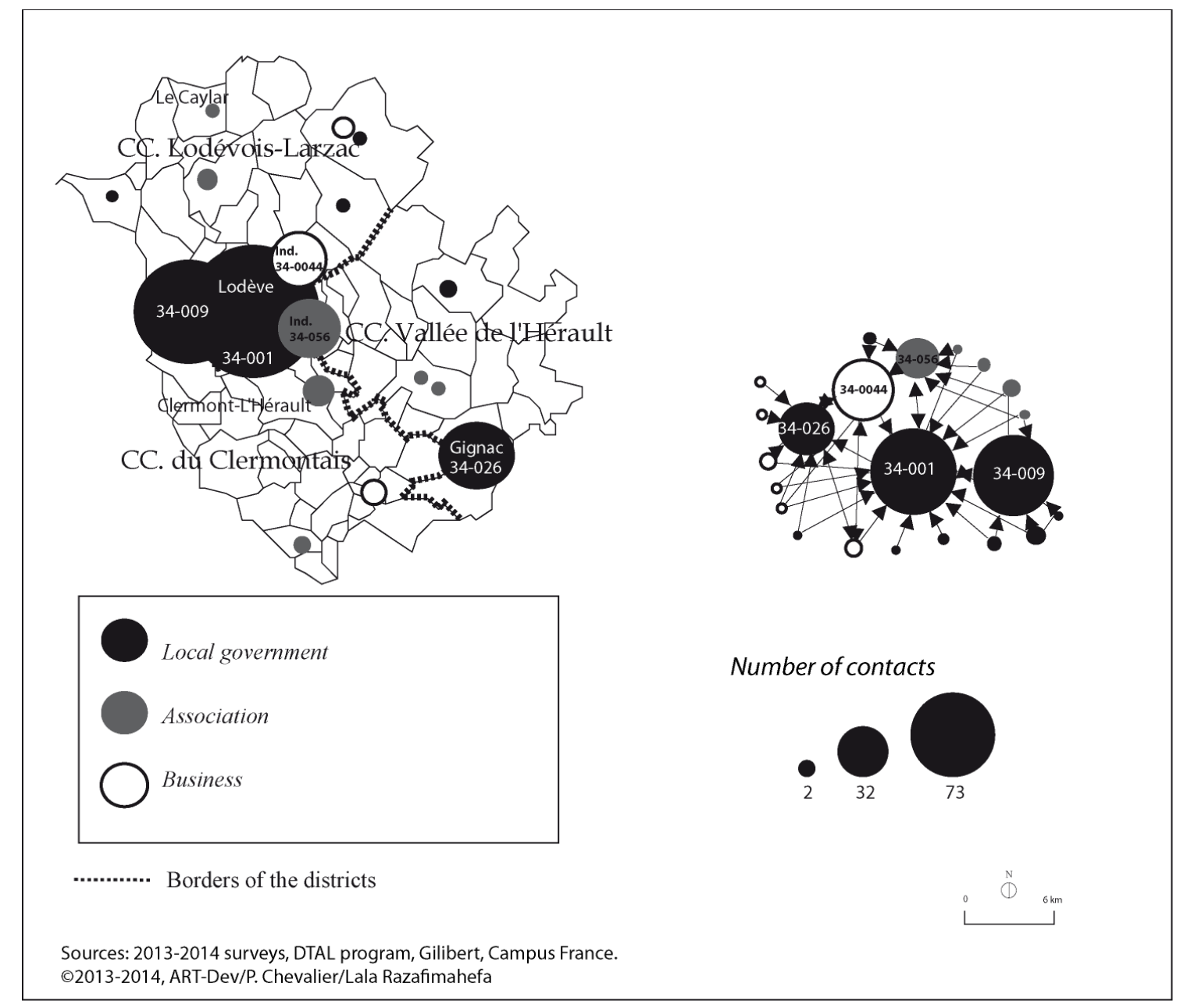

Fig 2. Spatial projection of the centrality regarding the Pays Cœur d'Hérault LAG.

This local network is therefore dominated by "integrating leaders" (elected officials as well as associations or businessmen), identified as people or groups initiating discussions which lead to the joint determination of public issues, their interest and the value in addressing them. This can include farmers, who rallied other association actors and Mayors around a real territorial project; or elected officials of the Pays Cœur d'Hérault LAG who managed to establish an integrating leadership based on an identity-building process of their territory and, thus, another form of collective mobilization.

\section{Joniškis: A network dominated by the rural community}

In Joniškis, the network is dominated by two individuals (ind. 31-27, ind. 31-42). These are two women who belong to two rural communities ${ }^{8}$ (Jakiškių-Maironio and Bariūnų) and who above all

\footnotetext{
8 In most cases, these rural communities associations were created by women with a higher level of education than the local male population and who worked as teachers, nurses or librarians.
} 
manage the LAG. Responsible as they were for the LAG's creation in 2004 during the LEADER+ programme and for the creation of their own rural community, their centrality within the network is high. As elected members of the district (savivaldybė), they also enjoy a reputation which far exceeds local boundaries. Through their knowledge of administrative procedures and of the LEADER programme's technical intricacies, they managed to appear indispensable to all of the LAG's rural communities and, more widely, to local stakeholders looking for information and help in setting up projects. As was the case with French elected officials, their centrality stems from their involvement in their own rural community, but they remain above all committed to the LAG's smooth operation since it guarantees their employment.

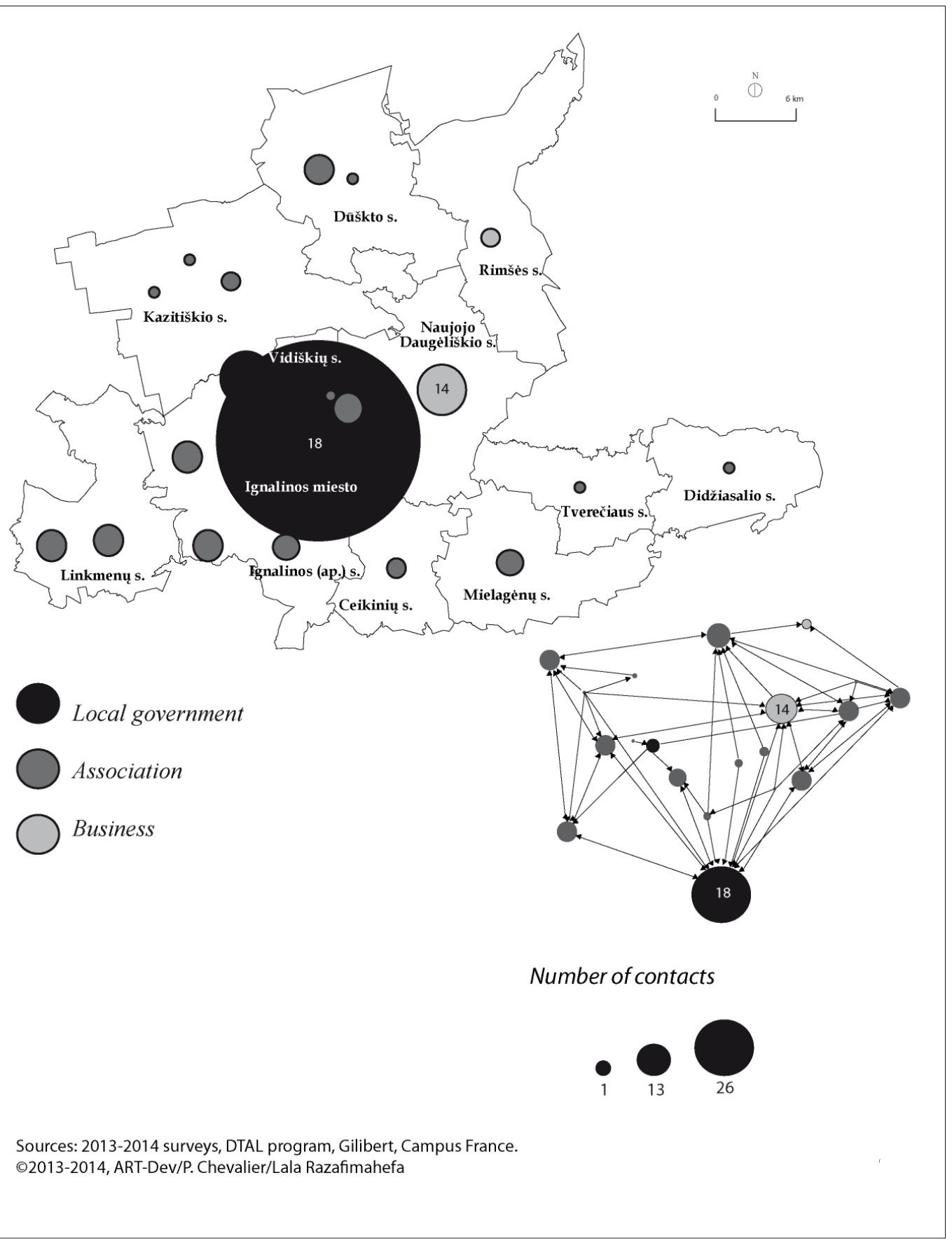

Fig 3. Spatial projection of the centrality regarding the Joniškis LAG.

The Joniškis LAG's success is linked to the involvement of these local actors, admittedly able to carry out a development project, but above all capable of enabling a dialogue between members of the network (Dedeire, Maciulyte, 2012). 


\section{Ignalina: A network dominated by politicians}

The network formed by the Ignalina LAG members seems poorly connected and shows weak integration. More than half of the respondents (9 out of 14) do not know all the LAG members, or a third of the LAG members are not known by other stakeholders. The knowledge and cooperation network is structured in several groups, and in the majority of cases, unilateral bonds link one group to another. The Ignalina LAG network is made up of an elite of two individuals involved in local political life. The pivotal individual in the stakeholder system is the Mayor of Ignalina (ind. 3214) whose reputation index (total of positive contacts) is the highest. For most respondents, he is seen as the most respected stakeholder. Hence, the Mayor is autonomous and in a position to benefit from rich income opportunities of all types (in particular in control) by becoming an essential intermediary for other stakeholders, themselves without any alternatives. The Mayor's dealings with the other groups of stakeholders are channelled through LAG members working as civil servants within the town but who, in most cases, also represent associations. The second person, who has a strong interaction with the Mayor and who enjoys authority within the LAG, is a local female councillor who has multiple roles (in charge of culture in the municipality, rural community president and president of the Family Farmers Union for the Ignalina district). The autonomy calculation has shown that the Mayor's relationships within the LAG network are dense, but that there are no links between the various groups of stakeholders themselves.

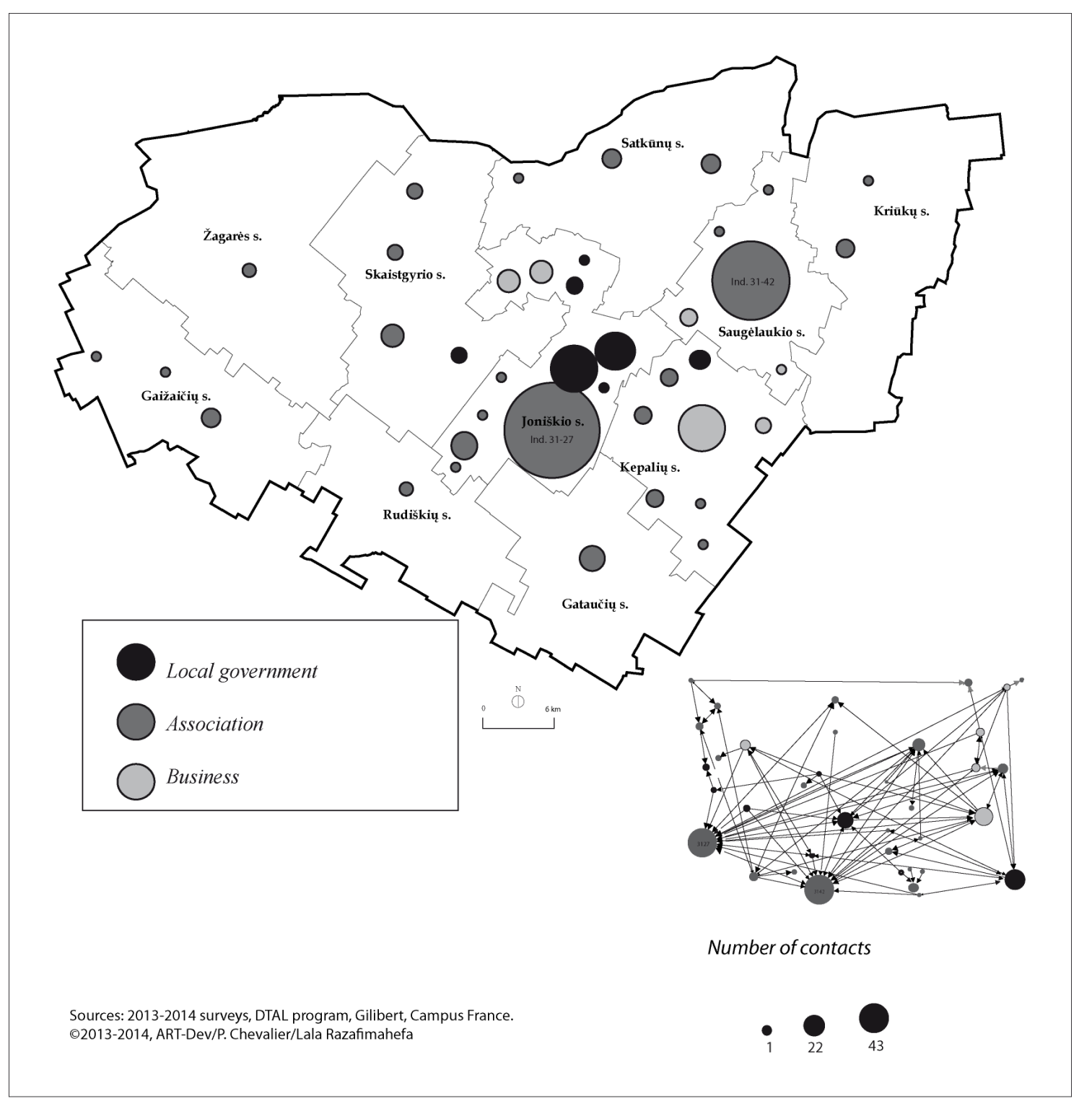

Fig 4. Spatial projection of the centrality regarding the Ignalina LAG. 
From the start, the municipality takes hold of the LEADER programme and treats it as an additional resource for carrying out its territorial development policy for the district. The Mayor controls the allocation of the programme's funding resources, thanks to the majority of the LAG Board members who belong to the municipality's direct sphere of influence through their work and who act as "followers". Rural communities and other NGOs, lacking strength and momentum, are marginalised in the reception of the LEADER model.

\subsection{Territorial dimension of the LAG network}

The map projection of the network centrality index shows the territorial dimension and the effects of polarization around stakeholders who seem to play a key role in the promotion of local development. As a whole, in all of the cases, peer relationships and their projection on the map confirm that the network is dominated to a large extent by local elites, made up of several Mayors and/or association leaders, and in particular, rural communities in Lithuania.

Overall, the relative density and connectedness of the relationships within the network help to understand the LAG structuring process from a double basis: a spatial basis - the ties that develop between LAG stakeholders are due to a geographical proximity effect - and a more organizational, relational or affinity basis (Rallet and Torre, 2004), as is the case between elected officials or rural community members. Within the LEADER programme, spatial proximity should eventually promote, in theory, proximity based on the sense of belonging to a larger community whose size matches that of the LAG's (Bouba Olga, Grossetti, 2008).

At the perimeter levels of LAGs containing a few dozen local communities and a few tens of thousands of inhabitants, geographical proximity seems to really play an essential role in the creation of social bonds. The extension of the project perimeter is based on the local communities' spatial contiguity. These entities define the framework of neighbourly relations: distances between localities, which are easily crossed, promote social interaction. It is worth noting that with the spread of personal means of transport and the particularly intense efforts made in the last twenty years to improve the infrastructure, the neighbourhood range is no longer limited to the sphere of the village, nor to the interknowledge society of the past. It has expanded to reach the dimensions of key areas used by various categories of rural groups (commuters, small businessmen, local politicians, development leaders, etc.). The difference is important between the small-sized Lithuanian LAGs and the wider Gévaudan-Lozère one whose surface area is five times bigger. Lastly, there seem to be large differences between the number of local authority partners (a ratio of 1 to 14), which reflects the level of fragmentation of the municipality network in France, whereas in Lithuania the small number of large-sized municipalities simplifies the local authorities' mode of representation and promotes interknowledge within the network.

\section{Local development projects as indicators of the mode of local public action mode}

Finally, it is through the examination of the project selection process that we can actually grasp the characteristics of the public action mode. Indeed, the development stage of local development strategies brings few relevant elements to judge them by. They are, on the one hand, strictly controlled by legislation and, on the other, highly formatted since they call upon service providers (consultants, development agencies, etc.) to draw up programme documents. However, the callfor-projects procedures convey the choices actually made by each LAG. The project analysis grid that we have adopted and that was applied to all four LAGs takes into account the funding allocation according to strategic priorities, the status of the project sponsors and the beneficiary municipalities. From this, it is possible to characterise the intentions of the decision makers who sit on the LAG's bodies, guide the programming of calls for projects and take part in their selection. What lessons can we draw from this? Does the funding allocation reflect the goals of the LEADER-led strategies? The four local scenes highlight the rationale that prevailed. 


\subsection{Gévaudan-Lozère: resource mobilisation by a "political leadership"}

Since the creation of the Gévaudan-Lozère LAG in 2007, six calls for projects have been launched (2008-2013). In total, 57 projects received funding under LEADER out of more than 150 submitted.

The projects sponsors vary according to the stated priorities. The vast majority of projects were submitted at the initiative of municipalities, associations close to them or semi-public companies (Sociétés d'Economie Mixte - SEM) with a view to carrying out renovation works on infrastructure or socio-cultural facilities intended for the local population. Seven projects relate to cultural heritage protection, i.e. the renovation of buildings of historical interest. Four of them originate from parastatal associations headed by Mayors. This is the case with the village of Apcher's medieval tower restoration project, which is sponsored by "The friends of the Land of Apcher" association whose president serves as Mayor of Malzieu-Ville, Vice-President in charge of culture at the General Council and President of the Communauté de Communes des Terres d'Apcher (the Lands of Apcher's association of municipalities). He also sits on the LAG Board. The four projects supporting tourism, leisure and sport activities are mainly sponsored by associations, whereas projects aiming to assist small production units and those aimed at agricultural diversification are carried by a few business leaders. Those businessmen, few in numbers, all put forward the same explanation. As the head of a stationery company explained, "the joint-financing of operations remains a major problem for all small businesses that, additionally, must systematically make advance payments (...) as the promised subsidies are always paid a posteriori, sometimes up to two years after the operations have ended".

Tab 5. Projects breakdown by beneficiary types (2008/2013) in the Gévaudan-Lozère LAG. Source: Board of Gévaudan-Lozère LAG (PHC Gilibert DTAL 2013)

\begin{tabular}{|l|c|c|c|}
\hline Sponsors & $\begin{array}{c}\text { Number of } \\
\text { beneficiary } \\
\text { projects }\end{array}$ & Amount (in Euros) & $\begin{array}{c}\text { Relative part of the } \\
\text { budget (\%) }\end{array}$ \\
\hline Local Institutions & 27 & 124,856 & 41 \\
\hline Associations & 21 & 112,212 & 36 \\
\hline Businesses & 9 & 67,424 & 23 \\
\hline Total & 57 & 304,492 & 100 \\
\hline
\end{tabular}

Here as well, the projects breakdown by beneficiary types reinforces the vision of a local policy focused on public infrastructure. The project sponsors are mainly municipalities and, to a lesser extent, associations whose ties with the municipalities are however sometimes tenuous. Out of 21 projects financed and sponsored by associations, 19 come from structures headed by a local politician. The "municipalisation" of the LEADER programme seems largely established even if it tends to hide behind associative structures championing the local authorities.

In terms of geographical breakdown, more than $70 \%$ of the projects and $82 \%$ of the funding are concentrated in the Lozère part of the LAG. This is clearly one of the effects of the obligation in France for projects to be jointly funded by Regional Councils. The Auvergne region, partner of the LAG and in which the Cantal and Haute-Loire départements are located, appears unwilling to co-finance the suggested projects within the LAG framework. With its different political persuasion from the majority of the Lozère politicians, it uses its central position to implicitly question the very existence of a LAG that yet features in its Contrat de projet État-Région (National/Regional Project Contract) since 2007. Could the local collective action be ignoring political conflicts? 


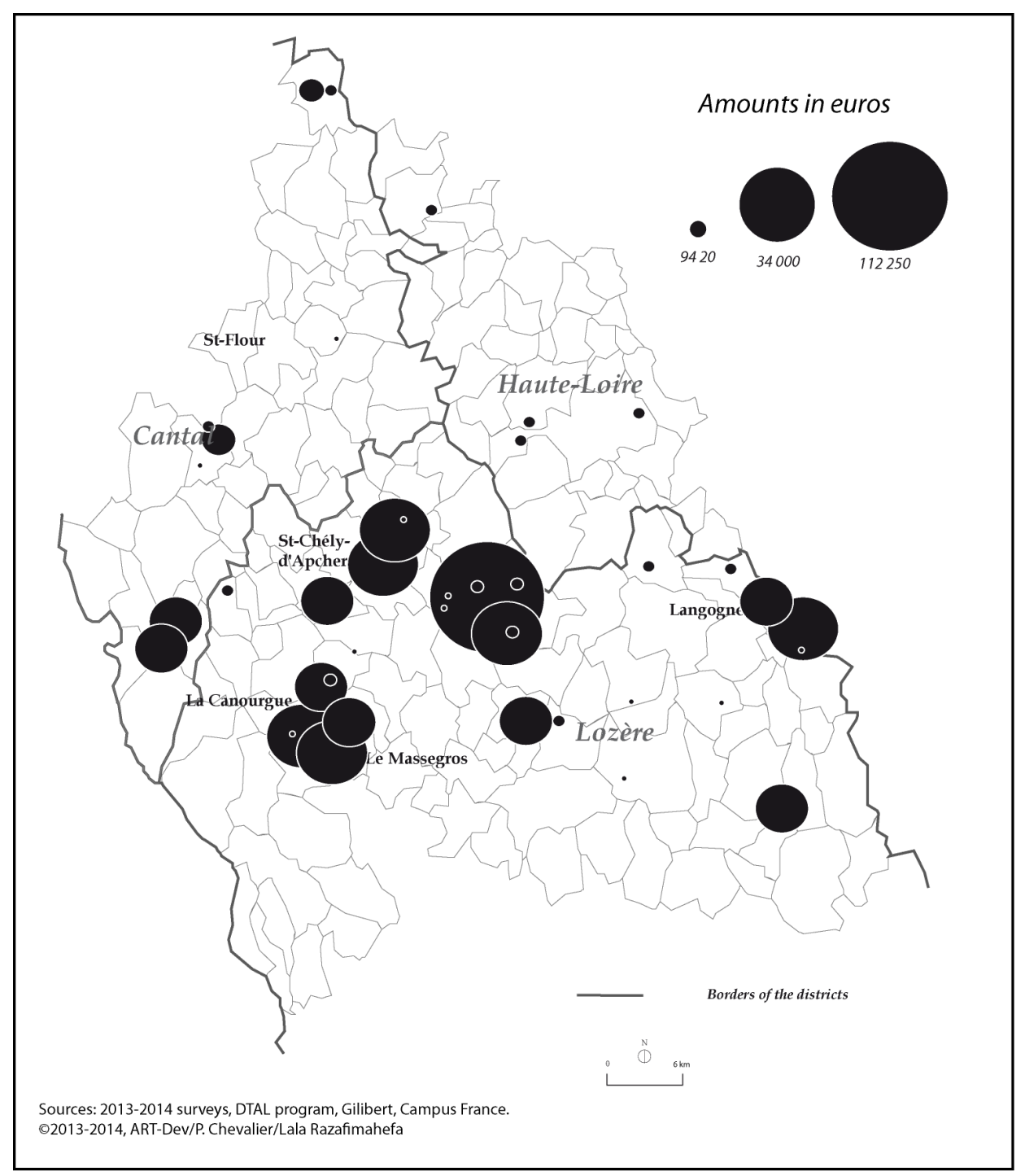

Fig 5. Projects breakdown in the Gévaudan-Lozère LAG (calls for tenders 2008-2013).

\subsection{Pays Cœur d'Hérault: tourism associations, LEADER programme's big "winners"}

Since the start of the LEADER 2007-2013 programme, at least five calls for tenders were launched in the Pays Cœur d'Hérault LAG. In total, 53 projects received funding for over 425,000 Euros. Project sponsors vary according to stated priorities. The vast majority of projects were submitted at the initiative of associations with a view to enhancing tourist sites or renovating socio-cultural facilities aimed at holidaymakers. This priority, initially set at $25 \%$ of the total strategy budget, ended up using more than $67 \%$ of the funding, the reality of the funded operations being quite remote from what was planned in the strategic framework documents.

While a small number of projects target the protection of cultural heritage, the vast majority originates from tourism associations (local tourist offices, the association of "gîtes operators of the Haute-Vallée de l'Hérault", the equestrian association of the Bosc, etc.). Asked about the reasons why this programme widely favoured projects sponsored by tourism associations, the LAG president - both Mayor and President of Lodève's tourism office - gave a pragmatic explanation: "Since municipalities can receive significant funding from elsewhere and are not able, pursuant to French legislation, to take a direct part in the funding of certain profit-making tourism projects (in particular, the renovation of privately owned gîtes and guest rooms), they step aside in favour of associations". These are "better prepared when it comes to putting the application together (...). They are better able to free up capacity for joint-funding (...), thanks in particular to the various subsidies received by municipalities (...) in order to take control of the tourism facilities operation". According to this same president, "businesses on the other hand 
need more time to master the complexity of the tender documents and to raise sources of cofinancing".

Associations - the LEADER programme's true winners - enjoy the ample support of municipalities to which they are very close. Very often, they help draw attention to these municipalities.

Tab 6. Projects breakdown by beneficiary types (2008/2013) in the Pays Cœur d'Hérault LAG. Sources: Field surveys by $P$. Chevalier/Pays Cœur d'Hérault LAG

\begin{tabular}{|l|c|c|c|}
\hline Sponsors & $\begin{array}{c}\text { Number of } \\
\text { beneficiary } \\
\text { projects }\end{array}$ & Amount (in Euros) & $\begin{array}{c}\text { Relative part of the } \\
\text { budget (\%) }\end{array}$ \\
\hline Local Institutions & 22 & 161,250 & 37 \\
\hline Associations & 21 & 181,450 & 42 \\
\hline Businesses & 10 & 83,178 & 21 \\
\hline Total & 53 & 425,878 & 100 \\
\hline
\end{tabular}

Ultimately, in this LAG, there are few economic sector projects that can directly boost local activity. However, businesses (in particular, winegrowers) are convinced that the actions in favour of local tourism development and rural heritage enhancement are key factors in boosting the winemaking activity.

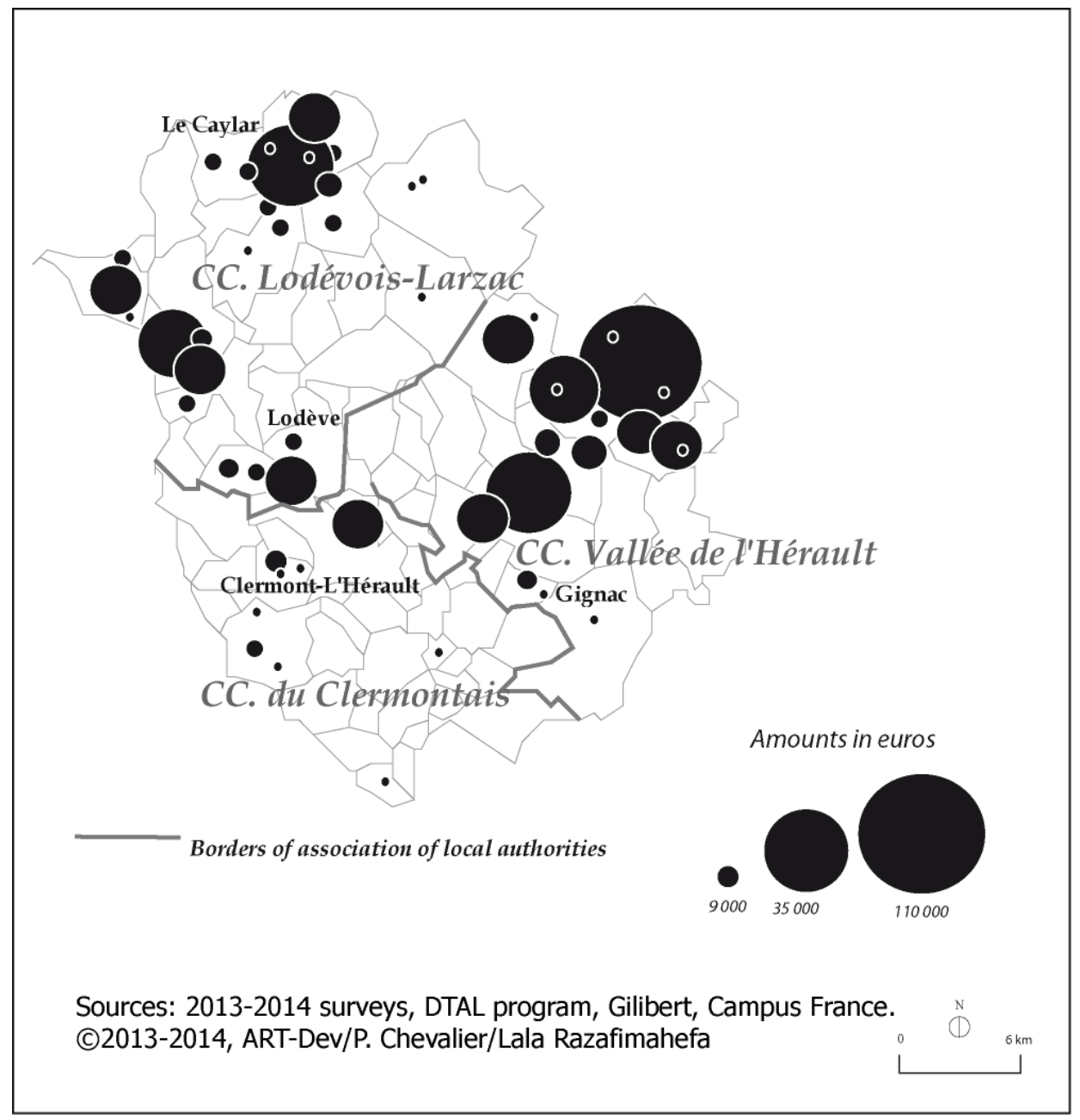

Fig 6. Projects breakdown in the Pays Cœur d'Hérault LAG (calls for tenders 2008-2013). 
From a geographical point of view, even if the three Communaute de Communes, members of the LAG, all received LEADER funding, the location map shows a "relatively high concentration" of projects in the most touristic villages of the western (Haute-Vallée de l'Hérault, Saint-Guilhemle-Désert region), northern (Causse du Larzac) and eastern regions (Haute-Vallée de l'Orb). By contrast, most of the main towns within the partnership had very few projects funded. In keeping with the LEADER approach, the objective of focussing funding on limited projects and areas seems partly met. Moreover, unlike the other LAGs, there is no significant correlation between the place of residence of the members represented in the LAG's bodies (Management Board, Steering Committee, Selection Committee) and the amount of funding received by the municipalities where they live. Instead, this map reflects the willingness to focus on promising tourism projects whose location reveals the unequal distribution of resources within the territory, and the political will to showcase them.

\subsection{Joniškis: a form of legitimisation of the LAG territory through the allocation of financial resources}

After seven calls for tenders, the Joniškis LAG has funded 62 projects. The main beneficiaries are rural communities associations for whom 41 projects were funded out of 61 . The renovation of village community buildings and the development of public recreational areas prompted great interest from these local stakeholders. The planned budget for the development of leisure centers, the renovation of village squares and other public spaces, the development of parks, areas along the edges of man-made lakes, sports halls and playing fields, was used in its entirety. Measures focused on the diversification of the economy, mainly aimed at businessmen, and the creation of craft workshops were much less popular: out of the first three tenders, no project was submitted for LEADER programme funding.

Geographically, the project breakdown is, generally speaking, linked to the LAG network's ability to spread its influence on its (sometimes very remote) periphery. This can be likened to a willingness to legitimise the territory in its most remote outskirts. Cronyism is negligible in the absence of local autonomy at municipality level, and therefore, neither politicisation nor municipalisation of the LEADER programme is possible. Thus, a large part of the funding covers distant local territories, such as Žagarè (nearly $30 \%$ ) or Skaistgirys (16\%). In these municipalities, the volume of population and the experience gained during LEADER + also seem to play a role in the geographical allocation of funds.

However, other factors affect this breakdown, such as the role played by development opportunities based on local resources. The largest funding amounts are allocated to areas benefiting from a combination of resource potential and ability to put projects together thanks to the local presence of a well-structured administrative body. This is the case with the Regional Natural Park in the Žagare area. More generally, projects which are more specific in their links to local resources and which are based on tourism or craft development, may explain the imbalances in the allocation of funds at municipality level.

At the same time, even if the project breakdown in value is concentrated on a few municipalities, an egalitarian logic, albeit partial, seems to exist. Some priorities established in the strategy are relevant to most municipalities and reinforce, on this basis, this egalitarian logic regarding funding allocation. It is, for example, the case for public infrastructure restoration or development projects which involves most of the municipalities.

More to the east of the LAG, some towns receive limited support from the LEADER grant scheme even though some efforts have been made. Today, the differences between the east and west of the LAG form a significant issue regarding the conduct and conditions of territorial development by questioning the links between governance and project territories. It would seem that paternalistic approaches also explain this breakdown of European funds that have a tendency to be concentrated in the areas where local stakeholders, weakened by their geographical remoteness, appear the least influential in the structuring of the network. 


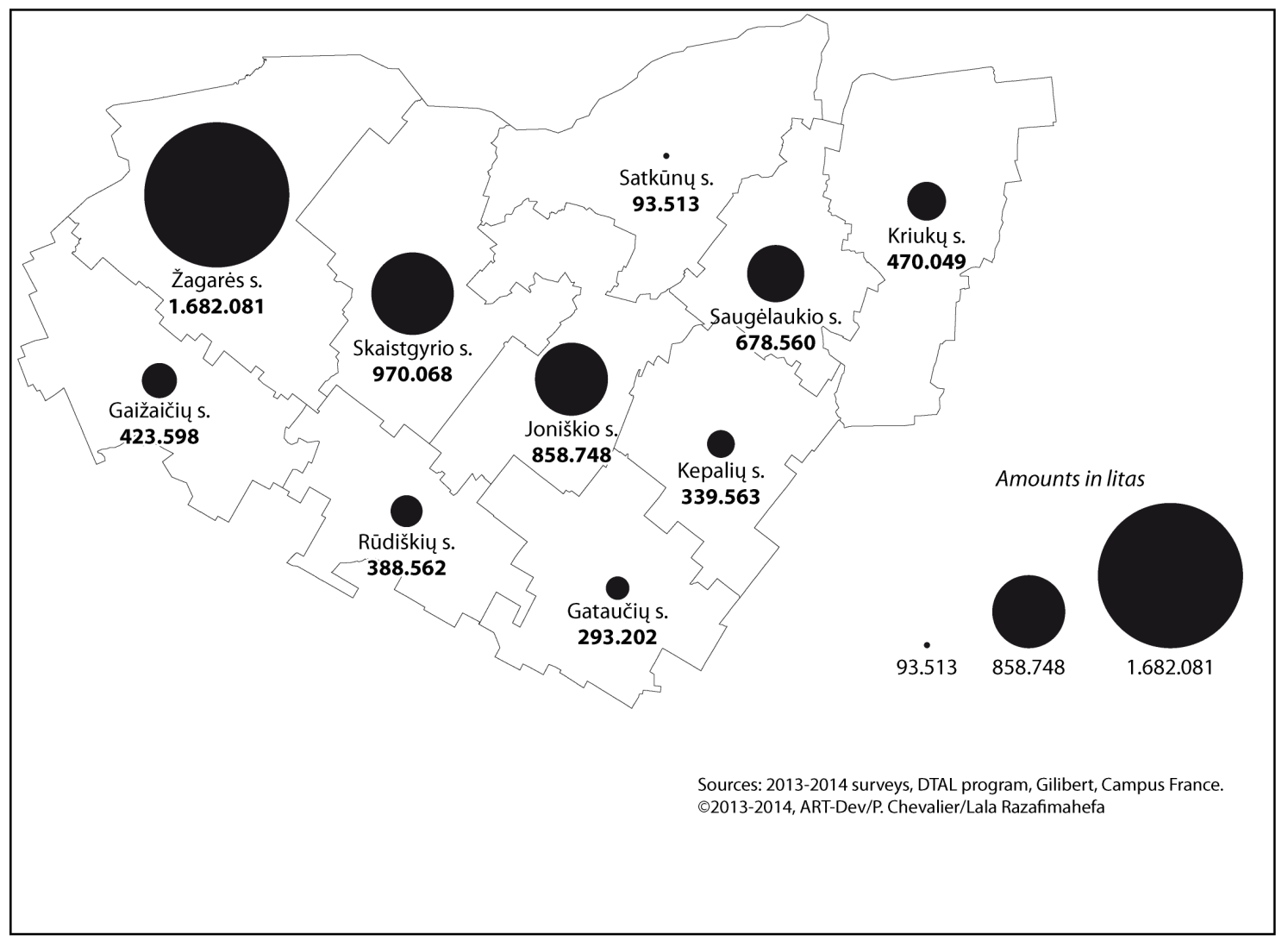

Fig 7. Projects breakdown in the Joniškis LAG.

Tab 7. Projects breakdown by beneficiary types in the Joniškis LAG (June 2013). Source: Field surveys PHC Gilibert DTAL 2013

\begin{tabular}{|l|c|c|c|}
\hline Sponsors & $\begin{array}{c}\text { Number of } \\
\text { beneficiary } \\
\text { projects }\end{array}$ & Amount (in Euros) & $\begin{array}{c}\text { Relative part of the } \\
\text { budget (\%) }\end{array}$ \\
\hline Local Institutions & 11 & 400,774 & 23 \\
\hline Associations & $\mathbf{4 1}$ & $\mathbf{1 , 0 0 9 , 4 5 4}$ & $\mathbf{5 8}$ \\
\hline Businesses & 9 & 338,592 & 19 \\
\hline Total & $\mathbf{6 1}$ & $\mathbf{1 , 7 4 8 , 8 1 9}$ & $\mathbf{1 0 0}$ \\
\hline
\end{tabular}

\subsection{Ignalina: a breakdown of projects unrelated to the structure of the social network}

The analysis of the territory carried out by the LAG consultants and members, together with the problems of local societies identified at the seniūnija ${ }^{9}$ level during a meeting with the inhabitants, have helped to define the LEADER programme's priorities and actions. The strategy, which was approved by the National Paying Agency in July 2009, includes two priorities: the first one is about developing the countryside through the modernisation of villages, and the second one deals with tourism development and rather reflects the global view on the region's future development as designed by local government and the LEADER programme consultants.

\footnotetext{
9 In 1995, the government replaced the local tier (apylinké) with municipalities without management autonomy (seniūnija). Deprived of political and financial independence, the new local municipalities have very little room to manoeuvre and depend on the district authorities (savivaldybé).
} 
Tab 8. Projects breakdown by beneficiary types in the Ignalina LAG (September 2014). Source: Field surveys PHC Gilibert DTAL 2014

\begin{tabular}{|l|c|c|c|}
\hline Sponsors & $\begin{array}{c}\text { Number of } \\
\text { beneficiary } \\
\text { projects }\end{array}$ & Amount (in Euros) & $\begin{array}{c}\text { Relative part of the } \\
\text { budget (\%) }\end{array}$ \\
\hline Local Institutions & $\mathbf{4 5}$ & $\mathbf{1 , 1 7 5 , 6 6 9}$ & $\mathbf{7 3 , 7}$ \\
\hline Associations & 21 & 319,091 & 20 \\
\hline Businesses & 11 & 101,091 & 6,3 \\
\hline Total & $\mathbf{7 7}$ & $\mathbf{1 , 5 9 5 , 7 7 9}$ & $\mathbf{1 0 0}$ \\
\hline
\end{tabular}

The implementation of the LEADER programme projects in the Ignalina LAG depends on the municipality and its Mayor who plays a key role in the LAG Board. The municipality remains a main stakeholder in the programme, thanks to the authority and power of the Mayor, as well as the financial and human resources of the local council. Priority has been given to the development of public infrastructure (around three quarters of the LEADER programme funding) with a focus on the building or renovation of public facilities. Contrary to the LEADER programme principles, the approach to local development in the Ignalina LAG's territory is based on a "top-down" principle. Half of the funded projects (45 out of 77 ) were submitted at the initiative of the municipality or the national Park. Most of the projects submitted relate to the improvement of drinking water management and purification (20 projects) as well as the refurbishment of public places (squares, streets, etc.) and the renovation of socio-cultural centres (9 projects). A small number of projects are aimed at leisure and sports facilities (8 projects) and are initiated by rural communities and the municipality.

The LEADER programme contributes little to the promotion of the LAG territory's tourism potential (25 projects or $15 \%$ of the total amount). Projects regarding the distribution of tourist information (brochures, books about tourist attractions, information boards, etc.) and cultural heritage protection are managed by stakeholders whose statuses vary (rural communities, municipalities and their cultural institutions, national park, parish). The creation of craft workshops is initiated by four rural communities. However, in the field of small company development, priority has been given to water-related tourism. Amongst the small number of projects sponsored by businessmen, half of the budget has been allocated to the purchase of canoes, of which $83 \%$ went to a single young entrepreneur.

In the Ignalina LAG, the LEADER programme instrumentalised by the municipality supported a policy of infrastructure investment in the district by focusing on the improvement of the quality of drinking water management. Projects regarding sporting and leisure facilities, as well as meeting room development projects that indirectly reinforce social bonds and community life at local level, were in the minority and in most of the cases, sponsored by the municipality (12 projects out of a total of 17 were taken on by the municipality or in partnership with it). Whilst the LEADER programme contributed to improve the quality of life, it did not sufficiently help support initiatives originating "at the bottom", nor consolidate village communities.

Unlike in the Joniškis LAG, the geographical breakdown of the projects depends, to a large extent, on the municipality that remains their main sponsor. Infrastructure and public facility projects that make-up three quarters of the programme budget are spread around all of the seniūnija, and at least one drinking water or waste water project was carried out on their territory. However, the breakdown in value shows a concentration on a few seniünija who benefited from several public facility projects (one water equipment project received two to four times more funding than other projects). The established correlation between the place of residence of the LAG Board members close to the Mayor (elected officials of the municipality) and the amount of funding received by the seniūnija suggests the existence of cronyism practices. The closeness of the district centre and the tourism resources of the national park also work in favour of funding acquisition. On the other hand, peripheral areas located on the border with Belarus benefited very little from the LEADER programme. 


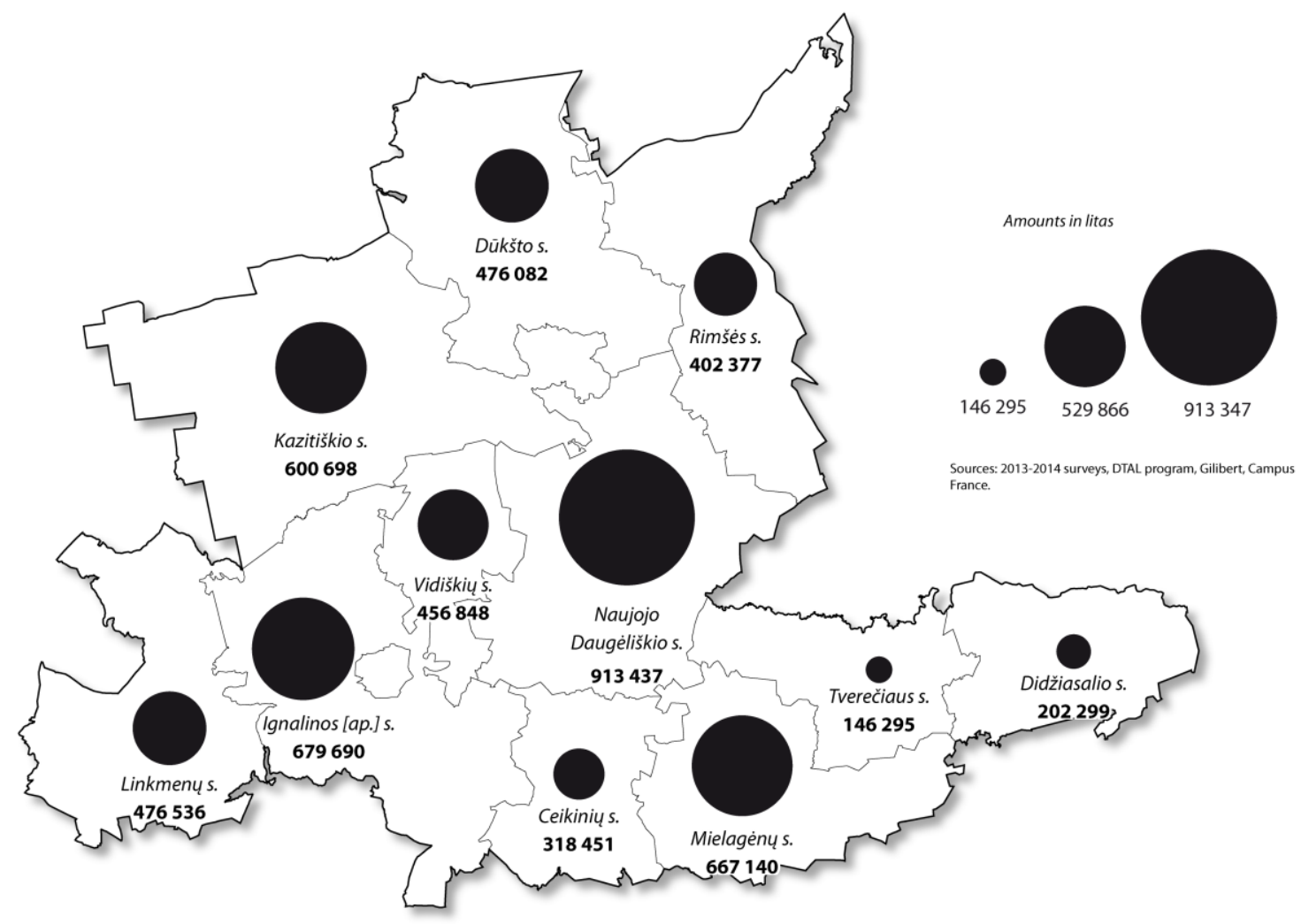

Fig 8. Projects breakdown in the Ignalina LAG.

\section{Learnings from LEADER implementation}

Has the transfer of the LEADER model offered by the European local development policy been successful or not? Does its application demonstrate the acquisition by stakeholders of a political ability to use the LEADER instrument in order to foster the revitalisation of rural areas, in particular, in Lithuania? An assessment of the effects of this policy transfer can be made, first at the level of the two countries under review, and then at the level of each of the four examined LAGs.

At national level, the mode of public policy transfer promoted by the EU gives France and Lithuania some room to manoeuvre, allowing them to adapt the LEADER instrument to the rationales for action that meet their public policy targets. National filters, in other words institutional elements, stakeholders and/or cultural factors that are likely to determine the way standards and European policies are received, are a powerful differentiation factor. The adaptive pressure exercised by the EU is diversely received and integrated by national prisms and is reflected in differentiated rationales for action in each country. The transfer process can lead to the absorption of the LEADER model offered by the EU, bring about its transformation or result in the rejection of the paradigm that promotes it.

The second series of learnings relates to the effects of the model's dissemination in rural areas. At local level, the LEADER instrument "resonates" with an area, a local society with its specific social ties, elites and resources. The institutional scheme's learning process occurs in the receiving context specific to each LAG. It is accompanied by an appropriation process of the local development approach during which stakeholders absorb new information and combine it with their past experience in order to incorporate it into actions which they plan to carry out in the future (Ripoll, Veschambre, 2005). This process depends on the mobilisation of the elites (Kovach, Kučerova, 2006) and the image they have of its value in the resolution of local problems. Whilst the implementation of the LEADER instrument is usually mastered by elected officials and managers, the often-limited dissemination of the LEADER principles to a handful of social stakeholders, as well as their modest involvement in strategy and project planning, highlight the transfer limitations. By cross-referencing the rationale for action that depends on national 
filters with the form of appropriation by recipient stakeholders at local level, the following typical situations can be determined.

Tab 9. Europeanisation through institutional transfer: the case of the LEADER model in the studied areas. According to Maurel, Chevalier (2013)

\begin{tabular}{|l|c|c|}
\hline \multicolumn{1}{|c|}{$\begin{array}{c}\text { LEADER model transfer } \\
\text { phases }\end{array}$} & \multicolumn{2}{|c|}{ Rationales for action } \\
\hline \multicolumn{1}{|c|}{ Forms of appropriation } & $\begin{array}{c}\text { Rationale for guidance } \\
\text { (France) }\end{array}$ & $\begin{array}{c}\text { Rationale for intervention } \\
\text { (Lithuania) }\end{array}$ \\
\hline $\begin{array}{l}\text { Level of appropriation } \\
\text { extended to a diversity of } \\
\text { local stakeholders }\end{array}$ & $\begin{array}{c}\text { LEADER model absorption } \\
\text { (Pays Cœur d'Hérault LAG) }\end{array}$ & $\begin{array}{c}\text { LEADER model adaptation } \\
\text { (Joniškis LAG) }\end{array}$ \\
\hline $\begin{array}{l}\text { Level of appropriation limited } \\
\text { to a "project class" (an elite) }\end{array}$ & $\begin{array}{c}\text { LEADER model adaptation } \\
\text { (Gévaudan-Lozère LAG) }\end{array}$ & $\begin{array}{c}\text { Inertia } \\
\text { (Ignalina LAG) }\end{array}$ \\
\hline
\end{tabular}

The maximum effect is reached when the rationale for guidance promotes a large appropriation of the LEADER model by the local stakeholders. This is the case for the Pays Cœur d'Hérault LAG, where the learning process spread over nearly two decades. The projects and achievements of this LAG show that the European model has been absorbed within the spirit on which it is based. Two other LAGs (Joniškis and Gévaudan-Lozère), less advanced in terms of learning, are on a path to adaptation of the LEADER model. They seek to overcome institutional obstacles, either in a rationale for guidance regarding the transfer process (French example), or within a more interventionist framework (Lithuanian example). However, in this last case, the rural communities' active participation offsets the influence of the top-down steering mode. Only the example of the Ignalina LAG reveals a situation of inertia that is the product of a top-down steering approach which locks the distribution channels of the LEADER model values. By instrumentalising strategies and projects for the benefit of municipal policies, the local elites express a form of rejection of the LEADER action paradigm.

Obviously, no conclusion regarding all of the partnerships run within the two studied countries can be drawn from the analysis of those four LAGs. Nevertheless, a number of key points seem to emerge, as the local space and national context layouts seem to play a key role in the formation and structure of cooperation networks. The LEADER scheme uptake usually stems from a complex mechanism whose operation combines three main elements in order to determine the forms of engagement of the local stakeholders in the cooperation network.

The first one refers to the level of involvement experience in local development approaches. Whilst in theory, the LEADER programme allows local stakeholders to mobilise their capacity for action and capture new resources, in reality this very much depends on the forms of involvement of the local communities whose learning ability regarding the local development model is linked to their cumulative experience. Broadly speaking, the "seniority" and diversity of local development mechanisms help structuring the networks of stakeholders on a broader basis of interknowledge and individual involvement. In LAGs where there has been a succession of local development schemes for more than twenty years (Pays Cœur d'Hérault LAG), the level of members' integration in the network seems high and the group cohesion asserted.

The socio-economic organization of the local space and its level of facilities then play a decisive role in the formation of cooperation networks: population densities, distances between places and local socio-economic structuring have an impact on the emergence of systems of stakeholders prone to engage in cooperation driven by the networking rationale.

Finally, the appropriation mechanism depends on the local action system's modus operandi that can strongly polarise collective action around a small number of local actors. The standards that regulate their actions lead them to develop their learning abilities, which sometimes goes together with the rolling-out of "informal spaces" of public policy reinterpretation and of "avoidance strategies" (within the meaning of Pfeffer \& Salancik, 1978). For example in 
Gévaudan-Lozère, Mayors are over-represented and therefore sit on the LAG Board with a different status in order to conform to the three-thirds regulation. In these areas, the professionalisation of such elites, who control greater amounts of funding and work full-time within their municipality and their LAG, continues to increase; this tends to reinforce the "project class" as defined by I. Kovách and Kucerova (2006), its professionalism and level of qualification. Linked to this increase of LAG members' capacity for action, some issues arise regarding their legitimacy, emphasising in particular the risk of cronyism and competition between the different municipalities.

\section{Conclusion}

What lessons can we draw from the model transfer? The first series of lessons relates to the Europeanisation of the political rationales for guidance or intervention by the national operator. The study of the critical stages of the transfer process points to the responsibility of the State operator in the transposition sequence of the LEADER programme. Far from being strictly followed by the two States, the principles of a bottom-up type of public action have suffered from a tightening of regulations which shifted the LEADER model's philosophy to the extent of separating it from the initial project (this is particularly the case in Lithuania). Formalised and embedded in a specific public action scheme (the National Countryside Development Programme), the LEADER instrument is no longer a faithful vehicle for the original model, as its basic principles may have been modified, and in some cases, distorted.

The second series of lessons relates to the effects of the model's dissemination in rural areas. At local level this time, the institutional scheme's learning process occurs in a particular context which is specific to each partnership or Local Action Group (LAG). The implementation of the LEADER model is inextricably linked to the contextualised modes of appropriation.

Field surveys conducted since 2013 in the four LAGs have highlighted the key role played by the local elites, in particular, the locally elected politicians in France and in the lithuanian LAG of Ignalina, or the rural community leaders in the Joniškis LAG in Lithuania. In France, the institutionalisation of the LEADER instrument in the hands of local politicians lies on a traditional view of the relationship between the ruler and the ruled. In Lithuania, given the flawed decentralisation and the lack of territorial authority at local level, the Joniškis LAG's leadership built itself around rural communities, just like the Ignalina LAG did around the political elite.

The general tendency for a group of local elites (political or rural community leaders) to "monopolise the LEADER programme" is primarily a way to address rural planning issues (upgrading facilities in Lithuania, infrastructure projects, etc.) in order to ensure the conditions of a local development often bounded to the municipal perimeter. The restricted spread of the LEADER principles in local society, whether in France or Lithuania, as well as the modest involvement of the stakeholders in strategy and project planning, highlight the limitations of the transfer mechanism.

Overall, these research results join Dax T. and Copus A. key findings (2016, p. 279) in the workshop documentation on "The future of rural development", according to which "The LEADER and CLLD approach, and the cooperation measures represent tools of high potential for participation, local development strategy processes and identity creation".

Academic References

[1] Bouba-Olga, O. \& Grossetti, M. (2008). Socio-économie de la proximité. Revue d'Economie Régionale et Urbaine, (3), 311-328. Doi: 10.3917/reru.083.0311.

[2] Callahan, R. (2007). Governance: the collision of politics and cooperation. Public Administration Review, 67(2), 290-301. Doi: 10.1111/j.1540-6210.2007.00714.x. 
[3] Chevalier, P. \& Dedeire, M. (2014). Application du programme leader selon les principes de base du développement local. Economie rurale, (342), 9-25. Doi: 10.4000/economierurale.4382.

[4] Chevalier, P., ed. (2012). Le modèle européen LEADER (2007-2013) - Logiques d'action et contextes de réception. Revue d'études comparatives Est-Ouest 43(3). Montpellier: Université Paul Valéry.

[5] Chevalier, P. (2014). Action locale et développement rural en Europe - Le modèle européen LEADER 2007-2013. Bern: Peter Lang. Doi: 10.3726/978-3-0352-6422-7.

[6] Dax, T. \& Copus, A. (2016). The future of Rural Development. In: Ragonnaud, G., ed., Research for AGRI Committee - CAP Reform Post-2020 - Challenges in agriculture (pp. 221-303). Brussel: European Parliament.

[7] Degenne, A. \& Forsé, M. (2005). Les réseaux sociaux. Paris: Armand Colin.

[8] Dedeire, M. \& Mačiulytè, J. (2012). Les communautés rurales, nouveaux acteurs du développement local en Lituanie Revue d'études comparatives Est-Ouest, 43(3), 145-172.

[9] Dolowitz, D. \& Marsh, D. (1996). Who learns what from whom? A review of the policy transfer literature. Political Studies 44, 343-357. Doi: 10.1111/j.1467-9248.1996.tb00334.x.

[10] Delpeuch, T. \& Vassileva, M. (2009). Contribution à une sociologie politique des entrepreneurs internationaux de transferts de réformes judiciaires. L'année sociologique 59(2), 371-402. Doi: 10.3917/anso.092.0371.

[11] Forsé, M. (2008). Définir et analyser les réseaux sociaux, les enjeux de l'analyse structurale. Informations sociales (147), 10-19.

[12] Keohane, N. O. (2010). Thinking about leadership, Princeton University Press.

[13] Kovach, I. \& Kučerová, E. (2006). The Project Class in Central Europe: the Czech and Hungarian Cases. Sociologia Ruralis, 46(1), 3-19. Doi: 10.1111/j.1467-9523.2006.00403.x.

[14] Lefebvre, R. (2005). La proximité à distance, typologie des interactions élus-citoyens. In Le Bart, C. \& Lefebvre, R., eds., La proximité en politique, usages, rhétoriques et pratiques (pp. 103-128). Rennes: Presse Universitaire.

[15] Lin, N. (1995). Les ressources sociales: une théorie du capital social. Revue Française de Sociologie 36(4), 685-704.

[16] Mačiulytè, J. \& Daugirdas, V. (2004). Décentralisation et collectivités territoriales en Lituanie. Revue d'études comparatives Est-Ouest 35(3), 99-118. Doi: 10.3406/receo.2004.1664.

[17] Mačiulytè, J. (2008). Développement rural en Lituanie: entre désengagement de l'Etat, émergence d'une société civile et apprentissage des outils européens. Revue d'études comparatives Est-Ouest 39(4), 63-80.

[18] Maurel, M.-C. \& Chevalier, P. (2013). Bilan du projet de recherche ALDETEC. http://recherche.univ-

montp3.fr/artdev/aldetec/aldetecpdf/Memoire_scientifique_ALDETEC.pdf.

[19] Maurel, M.-C. (2010). L'action publique "par le bas": I'approche LEADER en Europe centrale. Revue d'Etudes Comparatives Est-Ouest 39(4), 33-61.

[20] Mercklé, M. (2011). Sociologie des réseaux sociaux. Paris: La Découverte.

[21] Parrado, S. (2010). Le rôle du gouvernement central espagnol dans un État à niveaux multiples. Revue Internationale des Sciences Administratives 76(3), 495-514. Doi: $10.3917 /$ risa.763.0495.

[22] Pfeffer, J. \& Salancik, G. R. (1978). The external control of organizations: a resource dependence perspective. New York: Harper \& Row.

[23] Rallet, A. \& Torre, A. (2004). Proximité et localisation. Economie Rurale 280, 25-41. Doi: $10.3406 /$ ecoru.2004.5470. 
[24] Ripoll, F. \& Veschambre, V. (2005). L'appropriation de l'espace come problématique. In Ripoll, F. \& Verschambre, V., eds., L'appropriation de l'espace: sur la dimension spatiale des inégalités sociales et des rapports de pouvoir (pp. 7-15). Paris: L'Harmattan.

[25] Saurugger, S. \& Surel, Y. (2006). L'européanisation comme processus de transfert de politique publique. Revue Internationale de Politique comparée 13(2),179-211. Doi: 10.3917/ripc.132.0179. 